\title{
STANDARDIZED ILEAL DIGESTIBLE LYSINE REQUIREMENT OF WHITE COMMERCIAL LAYERS IN PEAK EGG PRODUCTION
}

\author{
NÍVEIS DE LISINA DIGESTÍVEL EM RAÇÕES PARA GALINHAS POEDEIRAS \\ LEVES NO PICO DE PRODUÇÃO
}

\author{
Silvana Marques PASTORE ${ }^{1}$; Paulo Cezar GOMES ${ }^{\mathbf{1}}$; Gabriel da Silva VIANA ${ }^{\mathbf{1}}$; Eliane \\ Aparecida da SILVA ${ }^{2}$; Will Pereira de OLIVEIRA ${ }^{3}$; Leonardo Valentino Soares BARBOSA ${ }^{4}$; \\ Alícia Zem FRAGA ${ }^{5}$; Warley Junior ALVES ${ }^{5}$ \\ 1. Doutor (a), Universidade Federal de Viçosa, Viçosa, MG, Brazil. 2. Doutora, Empresa Comércio e Indústria Uniquímica, São Paulo, \\ SP, Brazil. 3. Professor, Doutor, Instituto Federal Fluminense - Campus Bom Jesus do Itabapoana 4. Mestrando, Universidade Federal \\ de Minas Gerais/ Escola de Veterinária, Belo Horizonte, MG, Brazil. 5. Mestrando, Faculdade de Ciências Agrárias e Veterinárias - \\ FCAV (Unesp, Jaboticabal), Jaboticabal, SP, Brazil. silvanazoo@ hotmail.com
}

\begin{abstract}
This study was conducted to determine the standardized ileal digestible lysine (SID Lys) requirements for white commercial layers in peak egg production phase. A total of two hundred eighty-eight 24 week-old Hy-Line W-36 layers were randomly assigned to one of six treatments groups, with eight replicates of six hens each. A basal diet, SID Lys-deficient, was graded supplemented with L-Lysine $\mathrm{HCl}(78.4 \%)$ in order to produce experimental treatments $(6.0,6.6,7.2,7.8,8.4$ and $9.0 \mathrm{~g}$ SID Lys $/ \mathrm{kg}$ diet). Throughout the 16 -week-feeding trial (24 to 40 weeks of age) hens had free access to water and mash feed. Data were analyzed as one-way ANOVA and optimum SID Lys level for each dependent variable assessed were estimated using polynomial and linear broken-line regression model. Feed intake and SID Lys intake were both linearly enhanced by graded SID Lys levels. According to linear broken-line regression model, the breakpoint for egg production, egg weight, and egg mass occurred at 8.14, 8.56 and $8.35 \mathrm{~g}$ SID Lys $/ \mathrm{kg}$ diet, respectively. The breakpoint for feed conversion per egg mass $(\mathrm{kg} / \mathrm{kg})$ and per dozen of eggs $(\mathrm{kg} / \mathrm{dozen})$ occurred at 8.48 and $7.80 \mathrm{~g}$ SID Lys $/ \mathrm{kg}$ diet, respectively. Eggshell weight and albumen weight were unaffected by dietary SID Lys supply. Weight gain and yolk weight reached optimum values at 8.33 and $8.03 \mathrm{~g} \mathrm{SID} \mathrm{Lys/kg} \mathrm{diet,} \mathrm{respectively,} \mathrm{according} \mathrm{to} \mathrm{linear}$ broken-line regression model. In conclusion, SID Lys requirement for white commercial layers in peak egg production phase is $8.48 \mathrm{~g} / \mathrm{kg}$ diet, which corresponds to an average daily SID Lys intake of $813 \mathrm{mg} / \mathrm{hen}$.
\end{abstract}

KEYWORDS: Digestible amino acids. Egg quality. Laying hen. Nutritional requirements. Performance

\section{INTRODUCTION}

Genetic evolution of commercial layer strains has markedly improved hen productive rates. In regard to performance characteristics, over the last years, it was observed a substantial increase in laying hen egg production and persistence, higher egg mass values, beyond improvements in feed conversion rate. However, in order to optimize the expression of the optimum layer performance, the nutrient content of diets must be supplied in amounts, which meetsallhen nutritional needs. Poultry diets have been formulated based on ideal protein concept to supply digestible essential amino acids based on digestible lysine requirement. Basically, the ideal protein approach allows the reduction of dietary crude protein content with the concomitant supplementation of crystalline essential amino acids in order to provide optimum SID amino acids to SID Lys ratios (OLIVEIRA NETO et al., 2009).

Indeed, the ideal protein concept became more precise the meeting of SID amino acid layer requirements. However, since the SID essential amino acid requirements depend on SID Lys nutritional need, the establishment of laying hen requirements for SID Lys is crucial to warrant the adequate balance in amino acid profile and avoid impaired productivity. Rocha et al. (2009) recommended for ideal 24-to-40-wk-old white commercial layers a daily SID Lys intake of 759 $\mathrm{mg} / \mathrm{hen}$. Conversely, higher values of ideal daily SID Lys intake for white laying hens at peak egg production phase were reported by Rostagno et al. (2011) $(803 \mathrm{mg} / \mathrm{hen})$ and by the genetic line management guide (Hy-Line W-36, 2015) (805 $\mathrm{mg} / \mathrm{hen}$ ).

Because of the impact of genetic evolution in laying hen performance, their nutritional needs for amino acids, including SID Lys, must be periodically updated to maximize economical outputs (SAKOMURA et al., 2015). Therefore, this study was conducted to determine 24-to-40-wk-old white commercial layer SID Lys nutritional requirements in diets formulated based on ideal protein concept. 


\section{MATERIAL AND METHODS}

This study was conducted at the Poultry Research Farm of the Department of Animal Science of the Federal University of Viçosa, Minas Gerais, Brazil. All the procedures, which involved animal management were approved by ethics committee for animal care and use (protocol number 41/2012).

\section{Husbandry, diets and experimental design}

A total of two hundred eighty-eight 24-to40-wk-old Hy-Line W-36 hens were selected according to body weight $(1,317 \pm 0,03 \mathrm{~kg})$ and egg production rate $(92,5 \%)$ into the Poultry Research Farm flock. The layers were randomly assigned to one of 6 treatments groups, with eight replicates of six hens each. Experimental unit consisted of $68 \times$ $48 \times 38 \mathrm{~cm}$ (length $\mathrm{x}$ height $\mathrm{x}$ depth) stainless steel cages equipped with one self-feeder and one nipple drinker with six hens $\left(544 \mathrm{~cm}^{2} / \mathrm{hen}\right)$. Graded crystalline L-Lys $\mathrm{HCl}$ (78.4\%) was supplemented in a basal diet with $6.0 \mathrm{~g}$ SID Lys $/ \mathrm{kg}$ diet in order to produce experimental treatments $(6.0,6.6,7.2,7.8$, 8.4 and $9.0 \mathrm{~g}$ SID Lys $/ \mathrm{kg}$ diet) (Table 1). LGlutamic acid and sand was graded replaced by LLys $\mathrm{HCl}$ and essential crystalline amino acids to provide hens isonutritive diets. Basal diet was formulated based on corn and soybean meal to contain $149.58 \mathrm{~g} \mathrm{CP} / \mathrm{kg}$ diet and 2,900 kcal $\mathrm{AMEn} / \mathrm{kg}$ diet). Ideal digestible ratios of Met $+\mathrm{Cys}$, Thr, Trp, Val, Arg, Ile and Phe + Tyr relative to SID Lys were $103,81,28,96,103,80$, and $121 \%$, which corresponded to 3.0 perceptual point above the ratios recommended by Brumano et al. (2010), Rocha et al. (2013a), Calderano et al. (2012), Rostagno et al. (2011), Bregendahl et al. (2008), Rocha et al. (2013b) and Rostagno et al. (2011), respectively. Throughout the study, hens were provided mash feed and water ad libitum. The 16week feeding trial was divided into 4 periods of 28 days each. Daily photoperiod to which hens were exposed supplied 17L:7D. Temperature inside the experimental facility was daily recorded by two thermometers birds-height placed.

Table 1. Ingredient composition and nutrient content of the experimental diets (\% as-fed basis)

\begin{tabular}{lllllll}
\hline \multirow{2}{*}{ Ingredient (g/kg) } & SID Lys $(\mathbf{g} / \mathbf{k g})$ & & & \\
\cline { 2 - 7 } & $\mathbf{6 . 0 0}$ & $\mathbf{6 . 6 0}$ & $\mathbf{7 . 2 0}$ & $\mathbf{7 . 8 0}$ & $\mathbf{8 . 4 0}$ & $\mathbf{9 . 0 0}$ \\
\hline Corn $(7.88 \%)$ & 642.95 & 642.95 & 642.95 & 642.95 & 642.95 & 642.95 \\
Soybean meal $(45.22 \%)$ & 185.92 & 185.92 & 185.92 & 185.92 & 185.92 & 185.92 \\
Limestone (38.5\%) & 94.55 & 94.55 & 94.55 & 94.55 & 94.55 & 94.55 \\
Soybean oil & 25.80 & 25.80 & 25.80 & 25.80 & 25.80 & 25.80 \\
Dicalcium phosphate (24.4\%) & 15.98 & 15.98 & 15.98 & 15.98 & 15.98 & 15.98 \\
Salt & 5.25 & 5.25 & 5.25 & 5.25 & 5.25 & 5.25 \\
Potassium carbonate & 0.96 & 0.96 & 0.96 & 0.96 & 0.96 & 0.96 \\
Choline chloride (60\%) & 0.20 & 0.20 & 0.20 & 0.20 & 0.20 & 0.20 \\
Vitamin premix 1 & 1.00 & 1.00 & 1.00 & 1.00 & 1.00 & 1.00 \\
Mineral premix & 0.50 & 0.50 & 0.50 & 0.50 & 0.50 & 0.50 \\
Antioxidant & 0.10 & 0.10 & 0.10 & 0.10 & 0.10 & 0.10 \\
Sand & 1.00 & 1.98 & 3.02 & 4.00 & 5.35 & 6.67 \\
L-Glutamic acid (99\%) & 23.00 & 19.15 & 14.92 & 10.75 & 5.62 & 0.42 \\
L-LysHCl (78.4\%) & - & 0.78 & 1.55 & 2.33 & 3.10 & 3.88 \\
DL-Methionine (99\%) & 2.26 & 2.89 & 3.53 & 4.15 & 4.78 & 5.41 \\
L-Tryptophan (98\%) & 0.30 & 0.49 & 0.67 & 0.84 & 1.02 & 1.20 \\
L-Threonine (98\%) & 0.23 & 0.77 & 1.30 & 1.84 & 2.37 & 2.91 \\
L-Valine (98\%) & - & 0.56 & 1.14 & 1.73 & 2.30 & 2.89 \\
L-Isoleucine (99\%) & - & 0.17 & 0.66 & 1.15 & 1.64 & 2.13 \\
L-Arginine (98\%) & - & - & - & - & 0.61 & 1.28 \\
\hline Calculated composition & & & & & & 149.58 \\
\hline Crude protein (g/kg) & 149.58 & 149.58 & 149.58 & 149.58 & 149.58 & 149.58 \\
Metabolizable energy (kcal/kg) & 2,900 & 2,901 & 2,903 & 2,905 & 2,906 & 2,907 \\
Calcium (g/kg) & 40.20 & 40.20 & 40.20 & 40.20 & 40.20 & 40.20 \\
Non-phytate phosporous (g/kg) & 3.75 & 3.75 & 3.75 & 3.75 & 3.75 & 3.75 \\
Sodium (g/kg) & 2.25 & 2.25 & 2.25 & 2.25 & 2.25 & 2.25 \\
Potassium (g/kg) & 5.80 & 5.80 & 5.80 & 5.80 & 5.80 & 5.80 \\
Digestble & & & & &
\end{tabular}

Digestible amino acids $(\mathrm{g} / \mathrm{kg})$ 


$\begin{array}{lllllll}\text { Lysine }(\mathrm{g} / \mathrm{kg}) & 6.00 & 6.60 & 7.20 & 7.80 & 8.40 & 9.00 \\ \text { Methionine }(\mathrm{g} / \mathrm{kg}) & 4.20 & 4.82 & 5.44 & 6.05 & 6.67 & 7.29 \\ \text { Methionine + Cysteine }(\mathrm{g} / \mathrm{kg}) & 6.18 & 6.80 & 7.42 & 8.03 & 8.65 & 9.27 \\ \text { Triptophan }(\mathrm{g} / \mathrm{kg}) & 1.68 & 1.85 & 2.02 & 2.18 & 2.35 & 2.52 \\ \text { Threonine }(\mathrm{g} / \mathrm{kg}) & 4.86 & 5.35 & 5.83 & 6.32 & 6.80 & 7.29 \\ \text { Valine }(\mathrm{g} / \mathrm{kg}) & 5.78 & 6.34 & 6.91 & 7.49 & 8.06 & 8.64 \\ \text { Isoleucine }(\mathrm{g} / \mathrm{kg}) & 5.11 & 5.28 & 5.76 & 6.24 & 6.72 & 7.20 \\ \text { Arginine }(\mathrm{g} / \mathrm{kg}) & 8.08 & 8.08 & 8.08 & 8.08 & 8.65 & 9.27 \\ \text { Phenilalanine + Tyrosine }(\mathrm{g} / \mathrm{kg}) & 10.66 & 10.66 & 10.66 & 10.66 & 10.66 & 10.66 \\ \text { Phenilalanine }(\mathrm{g} / \mathrm{kg}) & 6.24 & 6.24 & 6.24 & 6.24 & 6.24 & 6.24 \\ \text { Leucine }(\mathrm{g} / \mathrm{kg}) & 11.71 & 11.71 & 11.71 & 11.71 & 11.71 & 11.71 \\ \text { Histidine }(\mathrm{g} / \mathrm{kg}) & 3.43 & 3.43 & 3.43 & 3.43 & 3.43 & 3.43\end{array}$

${ }^{1}$ Vitamin premix (amount per kg diet): vitamin A - 10,000 IU, vitamin D3 - 2,000 IU, vitamin E - $35 \mathrm{IU}$, vitamin K3 - $1.7 \mathrm{mg}$, vitamin B6 - $2.4 \mathrm{mg}$; vitamin B12 - $12 \mathrm{mg}$, pantothenic acid - $12.0 \mathrm{mg}$, biotin - $0.07 \mathrm{mg}$, nicotinic acid - $35 \mathrm{~g}$ and excipient. ${ }^{2}$ Mineral premix (amount per kg diet): manganese $-65.0 \mathrm{mg}$, iron - $50.0 \mathrm{mg}$, zinc - $60.0 \mathrm{mg}$; copper - $10.0 \mathrm{mg}$, iodine - $0.80 \mathrm{mg}$, selenium - $0.30 \mathrm{mg}$ andexcipient. ${ }^{3}$ butylated hydroxytoluene $/ \mathrm{kg}$ diet.

\section{Performance and egg quality measurements}

Egg production was daily recorded, whereas feed intake and SID Lys intake were measured every 28 days. All the eggs produced at the last five days of every 28 -d periods were weighed to determine average egg weight. Egg mass was estimated by multiplying egg production by weight. In order to determine feed conversion per egg mass $(\mathrm{kg} / \mathrm{kg})$ and per dozen $(\mathrm{kg} /$ dozen $)$, feed intake was divided by egg mass and dozen of produced eggs, respectively. At 40 wk of age, all the hens were weighed. Weight gain was calculated by the difference between final and initial body weight. At the last three days of every 28-d periods, two eggs produced by the experimental units were selected for egg trait analyses. The eggs were weighed and broken. The yolks were weighed apart the albumen. The eggshells was washed and weighed after an overnight drying. Finally, albumen weight was estimated subtracting the yolk and eggshell weight by the egg weight.

\section{Statistical analysis}

All collected data were analyzed as one-way ANOVA using PROC GLM procedure of SAS (SAS Institute Inc., Cary, NC). Orthogonal polynomial contrasts were used to determine the linear and quadratic effects of SID Lys ratios on the assessed data. In addition, linear broken-line regression model were computed by the NLIN procedure of SAS (ROBBINS et al., 2006). Standardized ileal digestible Lys requirement for each dependent variable assessed was estimated using quadratic and linear broken-line regression models. Cages containing six hens were considered as experimental units. Statistical model included experimental treatments (SID Lys levels) as fix effect: Yik $=\mu+$ SID Lys $_{\mathrm{i}}+$ eik. Where $\mathrm{Y}_{\mathrm{ik}}=$ dependent variable; $\mu=$ overall mean; SID Lys $_{i}=$ standardized ileal digestible lysine level ( $\mathrm{i}=6.0,6.6$, $7.2,7.8,8.4$ and $9.0 \mathrm{~g}$ SID Lys $/ \mathrm{kg}$ diet); $\mathrm{e}_{\mathrm{ik}}=$ random error term. Significant effects were considered when $\mathrm{P} \leq 0.05$.

\section{RESULTS AND DISCUSSION}

Means of daily average minimum and maximum temperature recorded inside the experimental facility were $20 \pm 5$ and $28 \pm 5^{\circ} \mathrm{C} \pm 3^{\circ} \mathrm{C}$, respectively. According to the Hy-Line W-36 management guide (Hy Line W36, 2015) the desirable ambient temperature for hens at production phase is $18-20^{\circ} \mathrm{C}$, which could be increased until reaching $25^{\circ} \mathrm{C}$, depending on ventilation system. Therefore, we assumed that at certain periods of this study the laying hens were exposed to heat stress condition.

Graded dietary SID Lys elicited a linear response $(\mathrm{P}<0.05)$ in feed intake and SID Lys intake (Table 2) as described by the following regression equations, respectively: $\hat{Y}=-103.29619+$ $108.122381 \mathrm{x} \quad\left(\mathrm{r}^{2}=0.99\right)$ and $\hat{\mathrm{Y}}=79.95286+$ $1.884286 \mathrm{x}\left(\mathrm{r}^{2}=0.98\right)$. The $58 \%$ increase in SID Lys intake is related to the dietary SID Lys concentration and to the $6 \%$ increase observed on feed intake as SID Lys supply ranged from 6.0 to $9.0 \mathrm{~g} / \mathrm{kg}$ diet. Similar results were reported by Trindade Neto et al. (2011) and Kakhki et al. (2016).

The feed intake response to SID Lys levels observed in the present study might be explained as a result of a positive feedback to a higher hen nutrient demand, which might have occurred in order to support the improvements in egg production caused by dietary SID Lys levels. 
According to Costa et al. (2014), feed intake regulation is strictly related to essential amino acids nutritional requirements or body protein accretion; and dietary amino acid profile may affect amino acid requirement by its effects on feed intake and the efficiency of amino acid deposition.

Graded SID Lys linearly increased $(\mathrm{P}<0.05)$ in $8 \%$ hen egg production (Table 2 ). Linear broken- line regression model, however, fitted egg production data better than linear regression, considering the sum of residual values. The breakpoint for egg production occurred at $8.14 \mathrm{~g}$ SID Lys $/ \mathrm{kg}$ diet, which corresponded to an egg production rate of $93.74 \%$

Table 2. Laying hen performance and egg quality responses to dietary SID Lys levels.

\begin{tabular}{|c|c|c|c|c|c|c|c|c|c|c|}
\hline \multirow[t]{2}{*}{ Item } & \multicolumn{6}{|c|}{ SID Lys(g/kg) } & \multirow{2}{*}{$\begin{array}{l}\mathrm{CV}^{1} \\
(\%)\end{array}$} & \multicolumn{3}{|c|}{ P-value } \\
\hline & 6.0 & 6.6 & 7.2 & 7.8 & 8.4 & 9.0 & & $\mathbf{L}^{2}$ & $\mathbf{Q}^{3}$ & $\mathbf{L B L}^{4}$ \\
\hline Feed intake(g/hen/day) & 91.11 & 92.31 & 93.84 & 94.59 & 96.00 & 96.66 & 2.95 & $<0.01$ & 0.71 & 0.01 \\
\hline $\begin{array}{l}\text { SID Lys intake } \\
(\mathrm{mg} / \text { hen/day })\end{array}$ & 546 & 609 & 675 & 737 & 806 & 863 & 2.94 & $<0.01$ & 0.81 & 0.01 \\
\hline Egg production (\%) & 86.03 & 88.33 & 90.21 & 92.56 & 93.03 & 94.42 & 2.98 & 0.01 & 0.23 & 0.01 \\
\hline Egg weight (g) & 57.77 & 57.88 & 58.34 & 58.90 & 59.60 & 59.56 & 1.49 & $<0.01$ & 0.31 & 0.01 \\
\hline Egg mass (g/hen/day) & 49.65 & 51.05 & 52.57 & 54.50 & 55.44 & 56.22 & 3.14 & $<0.01$ & 0.94 & 0.01 \\
\hline Eggshell weight (g) & 5.41 & 5.46 & 5.44 & 5.50 & 5.42 & 5.40 & 3.66 & 0.85 & 0.39 & 0.70 \\
\hline Albumen weight (g) & 38.66 & 38.66 & 38.98 & 38.77 & 39.21 & 39.28 & 2.63 & 0.08 & 0.76 & 0.46 \\
\hline Yolk weight (g) & 14.52 & 14.84 & 15.01 & 15.68 & 15.65 & 15.60 & 2.47 & $<0.01$ & 0.11 & 0.01 \\
\hline Weight gain (g/hen) & 0.21 & 0.28 & 0.30 & 0.35 & 0.38 & 0.39 & 19,37 & $<0.01$ & 0.26 & 0.01 \\
\hline
\end{tabular}

${ }^{1} \mathrm{CV}$-coefficient of variation; ${ }^{2}$ linear effect; ${ }^{3}$ quadratic effect; ${ }^{4}$ linear broken-line effect

(Figure 1). The optimum egg production obtained in this study was similar to those recommended by genetic line guide $(93.6 \%)$ ( Hy Line W-36, 2015).

The egg production responses here in observed to graded SID Lys levels may be due to the increase in plasmatic albumin concentration promoted by lysine (SHAHIR, 2004). For laying hens, plasmatic albumin is the main protein required for organism during egg protein synthesis in the oviduct (SMITH, 1978). Besides, meeting hen nutritional needs for digestible amino acids (e.g. lysine, methionine, isoleucine, valine e tryptophan) has shown to improved reproductive tissue morphology by enhancing magnum and uterus folds, which could reflect in positive effects on albumen and eggshell synthesis (FERNANDES et al., 2015).

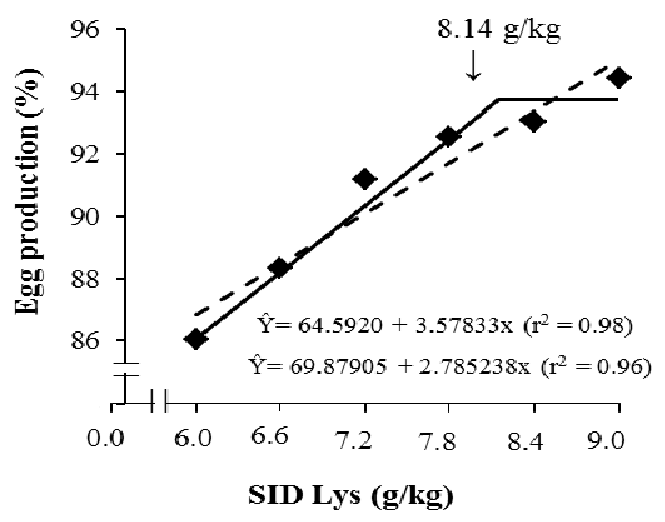

Figure 1. Effects of graded SID Lys on laying hen egg production from 24 to $40 \mathrm{wk}$ of age.

The increased egg production in response to SID Lys may be also associated with the higher supply of crystalline essential amino acids. In order to maintain equal the relative SID amino acid to SID 
Lys ratios, crystalline amino acids were graded added to basal diet. The increase in protein and amino acid ingestion enhances the pool of free amino acids in plasma, which induces pancreatic insulin secretion, which in turn, stimulates amino acid uptake by cells and consequently the egg protein synthesis (BOUYEH; GEVORGIAN, 2011).

Feed intake could also have influenced the behavior of egg production responses, once more nutrients were consumed when SID Lys content in diets was increased. Likewise, Trindade Neto et al. (2011) reported higher feed intake and egg production in hens given diets with higher SID Lys content. The authors estimated the nutritional needs of 24- to -28-wk-old brown commercial layers for optimum egg production at $8.05 \mathrm{~g} \mathrm{SID} \mathrm{Lys/kg} \mathrm{diet.}$ On the other hand, Rao et al. (2013) did not report any influence of dietary SID Lys on commercial layer feed intake and egg production from 39 to 74 wk of age.

Although egg weight has been linearly affected $(\mathrm{P}<0.01)$ by graded SID Lys levels, linear broken-line regression model fitted data better than linear regression. The plateau for egg weight was observed at $8.56 \mathrm{~g} \mathrm{SID} \mathrm{Lys/kg} \operatorname{diet}(\hat{\mathrm{Y}}=52.882+$ $\left.0.78 \mathrm{x}\left(\mathrm{r}^{2}=0.96\right)\right)$. This increase in egg weight could be related to the higher crystalline amino acid concentration in diets with higher SID Lys content, since essential amino acid supply was concomitantly increased with SID Lys. Once added to diets, essential amino acids like lysine, methionine and tryptophan lead to an increase in egg weight by improving yolk weight and albumen weight (TRINDADE NETO et al., 2011; BRUMANO et al., 2010; CALDERANO et al., 2012).
Graded SID Lys elicited a linear increase of $13 \%(\mathrm{P}<0.05)$ in egg mass (Table 2$)$. According to linear broken-line regression model, the estimated SID Lys level which promoted the breakpoint in egg mass value occurred at $8.35 \mathrm{~g}$ SID Lys/kg diet $(\hat{\mathrm{Y}}=$ $\left.33.462+2.67833 \times\left(r^{2}=0.98\right)\right)$. Positive effects of SID Lys on egg mass were also reported by Rocha et al. (2009), Pastore et al. (2015) and Kakhki et al. (2016).

In the current study, the greater egg mass value $(55.82 \mathrm{~g} / \mathrm{hen} /$ day $)$ was reached at $8.35 \mathrm{~g} \mathrm{SID}$ Lys/kg diet. This estimate is higher than the $7.77 \mathrm{~g}$ SID Lys/kg diet recommended by Rostagno et al. (2011). However, this difference becomes lower when the daily demand of SID Lys for egg mass production is considered. Considering hen feed intake, the requirements of SID Lys for egg mass found in this study was $799 \mathrm{mg} / \mathrm{hen}$, which is very close to the $803 \mathrm{mg} / \mathrm{hen}$ proposed by Rostagno et al. (2011) to equal hen egg mass production (55.8 $\mathrm{x}$ $55.5 \mathrm{~g} /$ hen/day).

The SID Lys nutritional requirements for egg weight $(8.56 \mathrm{~g} / \mathrm{kg})$ and egg mass $(8.35 \mathrm{~g} / \mathrm{kg})$ were higher than SID Lys requirement for egg production $(8.14 \mathrm{~g} / \mathrm{kg})$, which suggests that the SID Lys is firstly used to support egg production and has its excess subsequently used to internal component synthesis. Feed conversion rate per egg mass $(\mathrm{kg} / \mathrm{kg})$ and per dozen $(\mathrm{kg} /$ dozen) were both linearly improved $(\mathrm{P}<0.01)$ as graded SID Lys increased (Table 2). The breakpoint for feed conversion rate for egg mass $(\mathrm{kg} / \mathrm{kg}$ ) (Figure 2) and per dozen (kg/dozen) (Figure 3) occurred at 8.48 and $7.80 \mathrm{~g}$ SID Lys/kg diet, respectively.

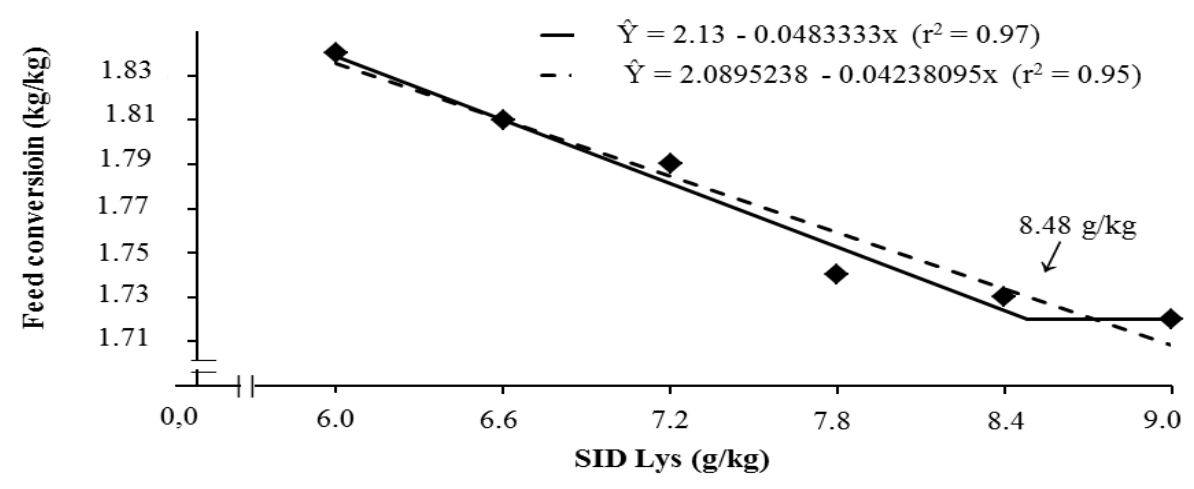

Figura 2. Effects of graded SID Lys on laying hen feed conversion rate $(\mathrm{kg} / \mathrm{kg})$ from 24 to 40 wk of age.

Our results demonstrated that the increase in egg mass was proportionally higher than the increase observed in hen feed intake. Such findings are consistent with Jardim Filho et al. (2010) who noted an improvement in feed conversion rate $(\mathrm{kg} / \mathrm{kg})$ and $(\mathrm{kg} /$ dozen) in response to dietary SID Lys supplementation in laying hens from 25 to 49 weeks of age. 


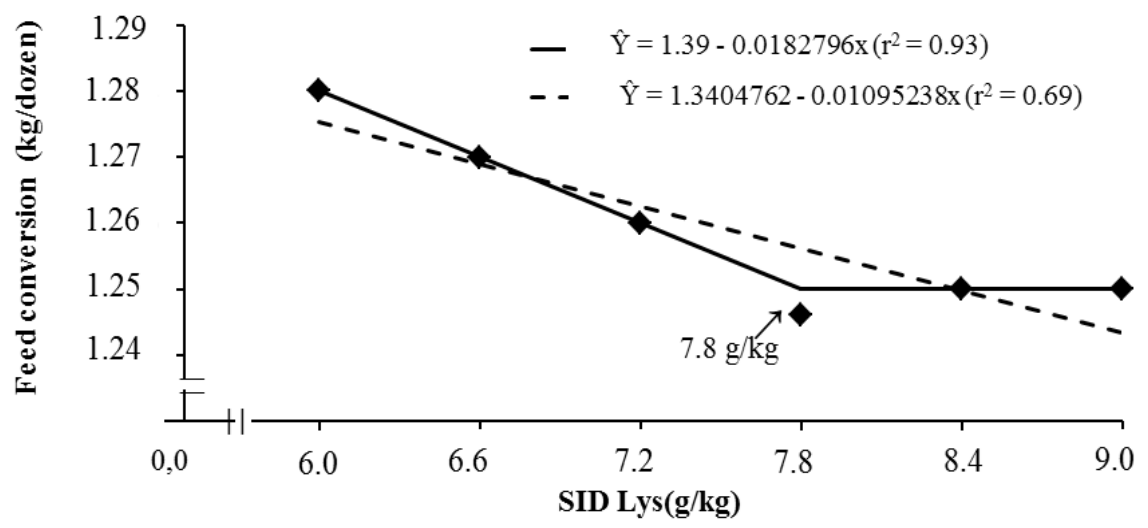

Figura 3. Effects of graded SID Lys on laying hen feed conversion rate ( $\mathrm{kg} / \mathrm{dozen})$ from 24 to $40 \mathrm{wk}$ of age.

Albumen weight and eggshell weight were both unaffected $(\mathrm{P}>0.05)$ by graded SID Lys levels, however a linear response $(\mathrm{P}<0.05)$ to increased dietary SID Lys supply was observed on yolk weight (Table 2). The breakpoint for yolk weight was observed at $8.03 \mathrm{~g}$ SID Lys $/ \mathrm{kg}$ diet, according to linear broken-line regression model $(\hat{\mathrm{Y}}=10,815$ $\left.+0,60833 x\left(r^{2}=0,99\right)\right)$. The precise meeting of hen requirements for essential amino acids has shown to enhance body nitrogen utilization, which become lower the nitrogen excretion. Since nitrogen excretion is strictly related to endogenous heat production, the lower nitrogen amount excreted by hens, the lower is the heat increment produced by organism. Net energy used to the maintenance of basal metabolism and productive functions is decreased when heat increment is higher. Therefore, lower heats increment value results in higher net energy balance. The increase observed on yolk weight could be explained by the more precise meeting of hen nutritional needs for amino acids, which could have enhanced the efficiency of nitrogen utilization and, therefore, provided higher net energy amount to yolk synthesis. Lysine supply may enhance both protein (Prochaska et al., 1996) and lipid accretion in yolk (Trindade Neto at al., 2011).

Similarly Pastore et al. (2015) did not report effects of SID Lys on albumen and eggshell weight, but observed higher yolk weight in hens fed diets containing $7.6 \mathrm{~g}$ SID Lys $/ \mathrm{kg}$ diet. Conversely, Kakhki et al. (2016) observed no influence of dietary SID Lys concentration on egg internal components of 32-to-44-wk-old Hy Line W-36 hens.

Weight gain was linearly improved $(\mathrm{P}<0.05)$ by graded SID Lys. Nevertheless, linear broken-line regression model fitted data better and provided the breakpoint for optimum weight gain at $8.33 \mathrm{~g} \mathrm{SID}$ Lys/kg diet, as described by the equation: $\hat{\mathrm{Y}}=$ $0,198125+0,0697917 \mathrm{x}\left(\mathrm{r}^{2}=0,97\right)$. Similar effects were reported by Rocha et al. (2009) who observed a linear increase in 24-to-40-wk-old Hy-Line W-36 laying hen weight gain as dietary SID Lys increased. Itis well acknowledged that lysine compounds the major fraction of skeletal muscle tissue (Tesseraud et al., 2001). Therefore, the increase in SID Lys content presumably enhanced muscle protein accretion, reflecting in higher weight gain rates.

\section{CONCLUSION}

In conclusion, SID Lys requirement for white commercial layers in peak egg production phase is $8.48 \mathrm{~g} / \mathrm{kg}$ diet, which corresponds to an average daily SID Lys intake of $813 \mathrm{mg} / \mathrm{hen}$.

RESUMO: Este estudo foi realizado para determinar a exigência de lisina digestível para galinhas poedeiras leves no pico de postura. Foram utilizadas 288 poedeiras Hy Line W-36 durante o período de 24 a 40 semanas de idade. As poedeiras foram distribuídas em delineamento inteiramente casualizado, com seis níveis de lisina digestível $(6,0 ; 6,6 ; 7,2$; 7,$8 ; 8,4$ e 9,0 g/kg de ração), oito repetições e seis aves por unidade experimental. Os níveis de lisina digestível na ração proporcionaram aumento linear do consumo de ração e de lisina digestível. O modelo Linear Response Plateau (LRP) foi o que melhor representou a distribuição dos dados para produção e peso dos ovos, ocorrendo os platôs nos níveis de lisina digestível de 8,14 e $8,56 \mathrm{~g} / \mathrm{kg}$, respectivamente. Para massa dos ovos e conversões alimentares por massa e por dúzia de ovos, os platôs ocorreram nos níveis de 8,$35 ; 8,48$ e 7,80 g/kg de lisina digestível, respectivamente. Os pesos de casca e de albúmen não foram influenciados pelos níveis de lisina da ração. $\mathrm{O}$ ganho de peso das aves e o peso de gema atingiram, respectivamente, os platôs nos níveis de 8,33 e 8,03 g/kg de lisina digestível. A exigência de lisina digestível para galinhas 
poedeiras leves no pico de postura é de $8,48 \mathrm{~g} / \mathrm{kg}$ de ração, que corresponde ao consumo diário de lisina digestível de 813 mg/ave.

PALAVRAS-CHAVE: Aminoácido digestível. Desempenho. Exigência. Galinhas. Qualidade de ovo

\section{REFERENCES}

BOUYEH, M.; GEVORGIAN, O. X. Influence of different level of lysine, methionine and protein on the performance of laying hens after peak. Journal of Animal and Veterinary Advances, v. 10, n. 4, p. 532-537, 2011. https://10.3923/javaa.2011.532.537

BREGENDAHL, K.; ROBERTS, S. A.; KERR, B.; HOEHLER, D. Ideal ratios of isoleucine, methionine, methionine plus cystine, threonine, tryptophan, and valine relative to lysine for white leghorn-type laying hens of twenty-eight to thirty-four weeks of age. Poultry Science, Oxford, v. 87, n. 4, p. 744-758, 2008. https://doi.org/10.3382/ps.2007-00412

BRUMANO, G.; GOMES, P. C.; DONZELE, J. L.; ROSTAGNO, H. S.; ROCHA, T. C.; MELLO, H. H. C. Níveis de metionina + cistina digestível em rações para poedeiras leves no período de 24 a 40 semanas de idade. Revista Brasileira de Zootecnia, Viçosa, v. 39, n. 6, p. 1228-1236, 2010.

http://dx.doi.org/10.1590/S1516-35982010000600010

CALDERANO, A. A.; GOMES, P. C.; DONZELE, J. L.; BARRETO, S. L. T.; VELLASCO, C.R.; MELLO, H. H. C.; LELIS, G. R.; ROCHA, T. C. Digestible tryptophan:digestible lysine ratio in diets for laying hens from 24 to 40 weeks of age. Revista Brasileira de Zootecnia, Viçosa, v. 4, n. 10, p. 2176-2182, 2012. http://dx.doi.org/10.1590/S1516-35982012001000006

COSTA, F. G. P. SILVA, J. H. V.; GOULART, C. C.; NOGUEIRA, E. T.; SÁ, L. M. Exigência de aminoácidos para aves. In: SAKOMURA, SILVA, N. K.; SILVA, J. H. V.; COSTA, F. G. P.; FERNANDES, J. B. K.; HAUSCHILD, L. Nutrição de não ruminantes. $1^{a}$ ed. Jaboticabal: FUNEP, 2014. Seção III, cap.4, p. 240-260.

HY-LINE DO BRASIL. Guia de manejo Hy-Line variedade W36. S. I.: s.n., 2013. 24p.

JARDIM FILHO, R. M.; STRINGHINI, J. H.; ANDRADE, M. A.; CAFÉ, M. B.; LEANDRO, N. S. M.; CARVALHO, F. B. Níveis de lisina digestível para poedeiras Hy-Line W-36 em produção. Revista Brasileira de Zootecnia, Viçosa, v. 39, n. 4, p. 787-795, 2010. http://dx.doi.org/10.1590/S1516-35982010000400013

KAKHKI, R. A. M.; GOLIAN, A.; ZARGHI, H. Effect of dietary digestible lysineconcentration on performance, egg quality, and blood metabolites in laying hens. The Journal of Applied Poultry Research, Oxford, v. 17, n. 0, p. 1-12, 2016. https://doi.org/10.3382/japr/pfw032

OLIVEIRA NETO, A. R.; OLIVEIRA, W. P. Aminoácidos para frangos de corte. Revista Brasileira de Zootecnia, Viçosa, v.38, suplemento especial, p. 205-208, 2009. http://dx.doi.org/10.1590/S151635982009001300021

PASTORE, S. M.; GOMES, P. C.; BARRETO, S. L. T.; VIANA, G. S.; SILVA, E. A.; ALMEIDA, R. L.; BARBOSA, L. V. S.; OLIVEIRA, W. P. Exigência nutricional de lisina digestível para galinhas poedeiras leves em produção. Ciência Rural, Santa Maria, v. 45, n. 8, p. 1496-1502, 2015.

http://dx.doi.org/10.1590/0103-8478cr20140661

PROCHASKA, J. F.; J. B. CAREY, SHAFER, D. J. The effect of L-Lysine intake on egg composition in laying hens. Poultry Science, Oxford, v. 75, n. 10, p. 1268-1277, 1996. 
RAO, S. V. R.; KUMARI, K. N. R.; LATHA, T. S.; RAJU, M. L. N.; PANDA, A. K. Influence of lysine levels on performance of layers with sub optimal protein in diet. International Journal of Food, Agriculture and Veterinary Sciences, Jaipur, v. 3, n. 1, p. 17-25, 2013. ISSN: 2277-209X (Online)

ROCHA, T. C.; GOMES, P. C.; DONZELE, J. L.; BARRETO, S. L. T.; MELLO, H. H. C.; BRUMANO, G. Níveis de lisina digestível em rações para poedeiras no período de 24 a 40 semanas de idade. Revista Brasileira de Zootecnia, Viçosa, v. 38, n. 9, p. 1726-1731, 2009. http://dx.doi.org/10.1590/S151635982009000900012.

ROCHA, T. C.; GOMES, P. C.; DONZELE, J. L.; ROSTAGNO, H. S.; MELLO, H. H. C.; RIBEIRO, C. L. N; TRONI, A. R. Digestible threonine to lysine ratio in diets for laying hens aged 24-40 weeks. Revista Brasileira de Zootecnia, Viçosa, v. 42, n. 12, p. 879-884, 2013a. http://dx.doi.org/10.1590/S151635982013001200007

ROCHA, T. C.; DONZELE, J. L.; GOMES, P. C.; MELLO, H. H. C.; TRONI, A. R.; VIANA, G. S. Ideal digestible isoleucine:digestible lysine ratio in diets for laying hens aged 24-40 weeks. Revista Brasileira de Zootecnia, Viçosa, v. 42, n. 11, p. 780-784, 2013b. http://dx.doi.org/10.1590/S1516-35982013001100003

ROSTAGNO, H. S.; ALBINO, L. F. T.; DONZELE, J. L.; GOMES, P. C.; OLIVEIRA, R. F.; LOPES, D. C.; FERREIRA, A. S.; BARRETO, S. L. T.; EUCLIDES, R. F. Tabelas brasileiras para aves e suínos: composição de alimentos e exigências nutricionais. 3.ed. Viçosa: Universidade Federal de Viçosa, 2011. $252 \mathrm{p}$.

SHAHIR, M. H. SHARIATMADARI, F.; MIRHADI, S. A.; ZAKERI, M.; VAZIRI, B. Use of physiological indicators for determining lysine requirement of the laying hen. Avian and Poultry Biology Reviews, v. 15, $\mathrm{n}$. 4, p. 247-250, 2004. https://doi.org/10.3184/147020604783638074

SMITH, W. K. The amino acid requirement of laying hen: models for calculation.1. Physiological Background. World's Poultry Science Journal, v. 34, n. 2, p. 81-96, 1978. https://doi.org/10.1079/WPS19960033

TESSERAUD, S.; TEMIM, S.; BIHAN-DUVAL, E. L.; CHAGNEAU, A M. Increased responsive ness to dietary lysine deficiency of pectoralis major muscle protein turnover in broilers selected on breast development. Journal of Animal Science, v. 79, n. 4, p. 927-933, 2001. http://10.2527/2001.794927x

TRINDADE NETO, M. A.; PACHECO, B. H. C.; ALBUQUERQUE, R.; SCHAMMASS, E. A. Lysine and zinc chelate in diets for brown laying hens: effects on egg production and composition. Revista Brasileira de Zootecnia, Viçosa, v. 40, n. 2, p. 377-384, 2011. http://dx.doi.org/10.1590/S1516-35982011000200020 